\title{
An Evaluation of the United States Experience in Controlling Forest Practices on Private Lands
}

\author{
by
}

\author{
R.D. Kreutzwiser ${ }^{1}$ and L.M. Crichton ${ }^{1}$
}

\begin{abstract}
The forest practice legislation of 14 states is examined critically to provide a basis for suggesting elements of a forest practice act for Ontario. Four types of legislation are identified: voluntary-selective, voluntary-comprehensive, mandatory-selective, and mandatory-comprehensive. The American experience suggests strongly that only mandatory-comprehensive legislation has had much impact on improving forest management on private land. This experience also suggests any effort to develop similar legislation for Ontario must give particular attention to how the administering agency is notified of intended activity on private land, the development standards for harvesting, regeneration, road construction and other practices, and procedures for monitoring and enforcing compliance with standards. A meaningful administrative commitment, including adequate staffing and funding, will be essential to any effort to enhance forest management on private land in Ontario.
\end{abstract}

\section{Résumé}

La législation des pratiques forestières de quatorze états a été étudiée de façon critique afin de procurer une base pour suggérér des éléments constituant une loi sur les pratiques forestières pour l'Ontario. Quatre types de législations ont été reconnus : volontaire sur certains aspects; volontaire de façon globale; obligatoire sur certains aspects; et obligatoire de façon globale. L'expérience américaine suggère fortement que seulement le type de législation obligatoire de facon globale a quelque impact sur l'amélioration de l'aménagement forestier dans les forêts privées. Cette expérience suggère que tout effort pour développer une législation semblable en Ontario doit particulièrement tenir compte de la façon dont l'agence en charge de l'administration est avisée des activités prévues dans les forêts privées, des pratiques reconnues d'exploitation, de régénération, de construction de route et des autres opérations, et des procédures pour surveiller et renforcer le suivi de ces pratiques. Un engagement significatif de l'administration, y compris un personnel en nombre suffisant ainsi que des fonds appropriés seront essentiels à tout effort d'amélioration de l'aménagement forestier dans les forêts privées de l'Ontario.

\section{Background}

Concern over future timber supplies, conflicts over the use of forest land, and increased public awareness of the consequences of poor forest practices on the environment have heightened interest in the management of public and private forests and led to much concern being expressed over the state of Canadian forests. In Ontario, in response to this concern and criticism over existing policies, the Ministry of Natural Resources (OMNR) has been active in recent years in reviewing its forestry programs (Armson 1976, OMNR 1982).

To date legislative changes have been made to improve the management of Crown land forests. They include the introduction of Forest Management Agreements which place responsibility for all aspects of forest management upon the timber company and set out prescriptions for forest practices and the performance standards to be met. In addition, under

1Department of Geography, University of Guelph, Guelph, Ont. N1G 2W1
The Ontario Environmental Assessment Act, OMNR is required to modify its forest management planning process so as to consider the environmental consequences of forest practices.

The OMNR is now focussing its attention to improving the situation on private land forests. There are a number of methods that governments can adopt to promote better forest practices; however, four approaches appear common: educational and advisory programs, incentive schemes (financial and direct assistance), guidelines, and regulatory programs (Society of American Foresters 1975, Ellefson and Cubbage 1980, OMNR 1982).

A review of the private land forestry programs established under current provincial legislation, The Forestry Act, The Woodlands Improvement Act and The Trees Act, shows a reliance on voluntary approaches whereby the landowner may approach the Ministry for assistance, whether it be advisory or financial, or to sign a management agreement 
under the Woodlands Improvement Program. The success of these programs, however, has been variable and they appear limited in the landowners they reach. This is in part due to inadequate funding (Aird 1980) and a lack of landowner awareness of these programs (Smyth and Nausedas 1981). What is clear is that there has been little attempt to develop comprehensive legislation controlling all aspects of forest practices in a more positive and integrative way or to introduce standards, criteria or policies for environmental regulation.

Discussions on new policy initiatives for private land forestry in Ontario centre on the Green Paper, Private Forest Lands - A Public Resource, which was released in 1982. An issue raised in this report and previously in the Armson report of 1976, which has received the support of the Ontario Professional Foresters Association, is that of introducing regulatory controls, in particular minimum standards of forest practices. So far Ontario's experience with regulating private forestry is restricted to The Trees Act which enables municipalities to pass and enforce bylaws to prevent the indiscriminate cutting of woodlots. However, a study of The Trees Act in 1982 questioned its effectiveness (Puddister and Kreutzwiser 1984).

In the United States, there is considerable state experience with legislative controls. Several states have introduced forest practice legislation in an attempt to control activities on private and, in some cases, public forest land. Initially the primary purpose of such legislation was to ensure timber productivity by preventing needless destruction and inappropriate consumptive uses. More recent legislation, prompted by amendments to the Federal Water Pollution Control Act, emphasizes environmental protection (Ellefson and Cubbage 1980).

The possibility that Ontario may adopt similar legislation suggests that an understanding of the American approach to controlling forest practices would be instructive. A number of studies have been completed in the United States, most particularly an overview assessment of the legislation published in 1980 by Ellefson and Cubbage and in-house assessments by several states of their experience with such regulations. The purpose of our study was to make a more rigorous evaluation of selected state forest practice legislation in the United States with a view toward identifying provisions for any similar legislation for Ontario.

A review of the literature on the US legislation identified the states with forest practice legislation. It was clear that a distinction could be made in the form the legislation takes; in some states compliance with the standards is voluntary whereas in others it is manadatory. It was also apparent the actual number of forest practices placed under control varied between states. These differences provided the basis for developing a four-class typology of forest practice legislation: voluntary-selective, voluntary-comprehensive, mandatoryselective, and mandatory-comprehensive.

The paper describes briefly the analytical framework and criteria adopted for the evaluation, summarizes some of the more significant findings concerning the US experience, and in conclusion raises issues that should be considered in developing forest practice legislation for Ontario.

\section{Approach}

To evaluate the selected forest practice legislation, it was necessary to develop a general analytical framework.
Development of the framework was guided by literature on policy evaluation (Weiss 1972, Sewell 1973, Jones 1977, and Kreutzwiser 1982). This involved identifying the legislation to be assessed and defining the goals of the legislation, selecting appropriate evaluative criteria, applying the criteria to the legislation to be assessed, and finally analyzing the information made available.

The evaluative criteria were derived from a review of the literature, in particular case study evaluations in resource management and from a consideration of the elements that several authors and organizations in the United States believe should be included in any forest practice act (Weyerhaeuser Company 1975, Society of American Foresters 1981). In addition, issues of concern identified in studies of forest management in Ontario are both reflected in, and provide further justification for, the criteria developed.

The criteria were developed to reflect four areas of interest: nature and scope of the legislation, nature of the requirements and standards, implementation process, and impact of the legislation. They are: clarity of policy goals, comprehensiveness, applicability, stringency of the requirements, provisions for monitoring and enforcing compliance, adequacy and application of sanctions, and nature and commitment of the administering agency.

The evaluation of forest practice legislation involves rating the extent to which it meets the criteria. To achieve consistency in the evaluation a simple rating scheme was developed to describe each criterion. In applying the criteria evidence from a variety of sources, including information gained through correspondence with those responsible for administering existing legislation and from the literature, was used.

\section{American Experience}

The evaluation methodology was applied to 14 states which represent the four types of leglislation identified in typology (Table 1). The results of the evaluation are summarized in Table 2.

Under the Vermont and New York legislation the forest practice rules are purely advisory in nature. This approach which relies on voluntary compliance does not appear to ensure the adoption of the forest practice standards by all forest owners and operators. In Vermont the standards apply to restocking only and are extensive in their application. In contrast New York regulates more forest practices but only on private land. Compliance with the standards was linked to a cooperative management agreement program between the landowner and the New York State forestry division. This has been abandoned recently as the division found that most landowners neglected to follow their management plans or the practices recommended in the guidelines ${ }^{2}$.

The administrative framework does not appear particularly strong in either state, control of forest practices is not a high priority among the programs administered by the forestry divisions, and funding for forestry programs in general is not considered adequate. As compliance with the standards is not mandatory, no inspection of operations is made in Vermont and only limited inspections are made in New York.

Mandatory-selective legislation is typical of older legislation enacted during the 1940 s which is concerned with

${ }^{2}$ Greason, R.A. Div. Lands and Forests, New York Dept. Environ. Conserv. Personal communication. 
Table 1. Classification of states by type of forest practice legislation.

\begin{tabular}{|c|c|c|}
\hline Type & State & Legislation \\
\hline $\begin{array}{l}\text { Voluntary- } \\
\text { Selective }\end{array}$ & Vermont & $\begin{array}{r}\text { Conservation and Development } \\
\text { of Forest Land Law, } 1977\end{array}$ \\
\hline $\begin{array}{l}\text { Voluntary- } \\
\text { Comprehensive }\end{array}$ & New York & $\begin{array}{r}\text { Forest Practices Act, } 1946 \\
\text { (amended 1980) }\end{array}$ \\
\hline $\begin{array}{l}\text { Mandatory- } \\
\text { Selective }\end{array}$ & $\begin{array}{r}\text { Maine } \\
\text { Maryland } \\
\text { Massachusetts } \\
\text { Mississippi } \\
\text { Virginia }\end{array}$ & $\begin{array}{r}\text { Land Use Regulation Law } \\
1969 \text { (amended 1981) } \\
\text { The Seed Tree Law, 1977 } \\
\text { Forest Cutting Practices Act, } \\
1983 \\
\text { Forest Harvesting Act, } 1944 \\
\text { Seed Tree Act, 1955 } \\
\text { (amended 1972) }\end{array}$ \\
\hline $\begin{array}{l}\text { Mandatory- } \\
\text { Comprehensive }\end{array}$ & $\begin{array}{r}\text { Alaska } \\
\text { California } \\
\text { Idaho } \\
\text { Nevada } \\
\text { New Mexico } \\
\text { Oregon }\end{array}$ & $\begin{array}{r}\text { Forest Resources and Practices } \\
\text { Act, 1979 } \\
\text { Z'berg Nejedly Forest Practices } \\
\text { Act, 1973 } \\
\text { Forest Practices Act, 1974 } \\
\text { (amended 1980) } \\
\text { Forest Practices Act, 1955 } \\
\text { (amended 1973) } \\
\text { Forest Conservation Act, 1978 } \\
\text { Forest Practices Act, 1971 } \\
\text { (amended 1979) } \\
\text { Forest Practices Act, 1974 }\end{array}$ \\
\hline
\end{tabular}

ensuring regeneration. Newer legislation in Maine and Massachusetts does recognize broad environmental goals. This legislation tends to be more restricted in its application and less stringent in its requirements of landowners and operators; however in Maine and Massachusetts owners and operators are required to notify the administering agency before certain activities commence.

In Mississippi, Maryland and Virginia the standards are very specific in nature and limited to natural regeneration. Many are considered to be outdated and steps are being taken to amend them to recognize modern forestry principles. Landowners now have the option of preparing a management plan which exempts them from compliance with the act but it must contain adequate measures for artificial regeneration. In Maine and Massachusetts road construction standards are aimed at reducing soil erosion.

In all the states with mandatory-selective legislation, administrative support appears important in determining successful implementation of the legislation. In most states no specific funding or personnel are assigned to forest practices and, except in Massachusetts, enforcement seems minimal. A major difficulty experienced in checking for compliance is knowing where all the harvesting operations are occurring. Penalties for non-compliance tend to be limited to fines and stop-work orders that close down operations in violation of the

Table 2. Forest practice legislation evaluation summary.

\begin{tabular}{lrrrr}
\hline & & \multicolumn{2}{c}{ Type of forest practice legislation } \\
\cline { 2 - 6 } Criteria & $\begin{array}{r}\text { Voluntary- } \\
\text { Selective }\end{array}$ & $\begin{array}{r}\text { Voluntary- } \\
\text { Comprehensive }\end{array}$ & $\begin{array}{r}\text { Mandatory- } \\
\text { Selective }\end{array}$ & $\begin{array}{r}\text { Mandatory- } \\
\text { Comprehensive }\end{array}$ \\
\hline 1. Clarity of policy goals & General & General & Specific & General \\
\hline 2. Comprehensiveness & Selective & Comprehensive & Slective & Comprehensive \\
\hline 3. Applicability & Extensive & Extensive & Extensive \\
(a) geographical coverage & Both & Private & Mainly private & Both \\
(b) ownership (private, public) & No minimum & No minimum & No minimum & Minimum \\
(c) size of property & Yes & No & Yes \\
(d) activities exempt & & & Yes
\end{tabular}

\section{Stringency of regulations}
(a) stringency of standards
(b) requirements

Not stringent

None

Not stringent

None
Moderately stringent

In newer legislation notifications
Moderately stringent

Nofications and permits

\section{Provisions for compliance}
(a) inspection procedures
(b) operations inspected
(c) reporting of violations

In general no formal inspection

Limited

Agency

Limited-fines

No

6. Adequacy and application of sanctions
(b) performance bonds
(c) procedure for applying sanctions
(a) sanctions available

Weak
Inspections made on a regular basis

Priority system to determine inspections Various

Extensive

7. Nature and commitment of agency
(a) responsibility for administration
One agency
One agency
One agency
One agency - input from other agencies encouraged
(b) agency status
Established
Established
Established
(c) funding
Inadequatg
(d) personnel
Adequate
Inadequate
Adequate
Established
Adequate
Adequate

Only in Nevada

Effective in most states 
act until the operator agrees to comply. There is, however, a tendency among the states to settle less serious violations on an individual basis with the landowner.

The remaining states examined, Alaska, Oregon, Washington, California, Idaho, Nevada and New Mexico, enforce mandatory-comprehensive legislation that regulates a wide range of forest practices to achieve a number of objectives. In addition to stating broad goals related to maintaining timber productivity, most of the legislation recognises the multiple-use of forests and includes general goals related to protection of other forest-derived values such as water and soil conservation, wildlife habitat, and recreation.

There are many similarities in legislation. All seven states regulate activities on both private and public forest land but in some states the regulations are not applicable throughout the entire state or are not enforced on property below a certain minimum size. In common with mandatory-selective legislation, provisions exist in certain states to exempt landowner or operator compliance with the regulations if they have an approved management plan. However, in a recent review of the Idaho act (Idaho Dept. of Lands 1984), it was recommended that this exemption be abolished as it did not ensure adequate levels of forest practice.

In contrast to other types of legislation, this approach is more demanding in its requirements of landowners and operators. In all states owners or operators are required to advise the administrative agency of intended forest practices. The common methods are a notification scheme whereby the agency must be informed several days or weeks before an activity begins and a permit system that requires a timber harvesting plan to be prepared and approved prior to harvesting.

The legislation generally authorizes an independent board to establish the rules and standards for forest practices. In addition, a number of states have created regional advisory committees which report to the state board on a specific geographical area. The forest practices regulated in each state tend to be timber harvesting, regeneration, road construction, slash disposal and the use of chemicals. Generally, minimum standards are specified which may vary among forest regions in the state. The majority of standards are highly stringent; however, some, particularly those relating to erosion control and waterway protection, are more general and could be open to broad interpretation.

On the whole procedures for monitoring and enforcing the legislation are stronger and administrative commitment is greater. In the major timber producing states, specially employed forest practice officers or foresters are responsible for enforcing the regulations. The number and type of inspections made varies considerably. Three types of inspection are common (pre-operational, preventive and post-operational) and several states have developed criteria to determine the priority of operations for inspection. These can be based on the scale and location of the operation, complaints, risk and environmental damage, and requests.

Although most states have a range of sanctions available, reliance is placed on fines or corrective action at the owner's expense. Many states are reluctant to enter into lengthy and costly court cases; as a result attempts are made to resolve the problem by discussion with the violator rather than automatic recourse to prosecution. Compliance rates, particularly in Oregon, California and Idaho, are reported as being high and have shown increases in recent years as knowledge and understanding of the regulations have become more widespread.

\section{Implications for Ontario}

Given the social, economic and environmental benefits of private land forestry to Ontario but accepting present concerns over its level of management, forest practice legislation would seem to have relevance in that it offers the opportunity to improve forest management. As evidence suggests that mandatory-comprehensive legislation has had some success in improving forest management and minizing environmental damage from forestry activities, this approach is favoured. Voluntary approaches and mandatory-selective legislation have had limited results due to problems in encouraging compliance and the limited scope of the legislation.

It is clear from the American experience that if Ontario adopts some form of regulatory control, a number of measures should be included in the legislation. It must recognize the multiple benefits of forests and aim to improve forest management and protect the environment by requiring the application of sound forest practices. The legislation should be applicable to all private forest land in Ontario and landowner and operator compliance should be mandatory.

Some form of notification should be introduced to inform the OMNR of intended forest practices. This would provide much needed information on timber operations in Ontario and aid the implementation and enforcement process. The legislation should specifiy who is responsible for submitting the notification and forms should be issued outlining the information required.

Standards should be developed for a range of forest practices, in particular, timber harvesting, regeneration, and road construction; and responsibility for standards should be placed with an independent board. This would allow for input from a number of experts such as wildlife biologists, landscape architects, and hydrologists and from representatives of the forest industry and landowner associations. Regional advisory committees could be formed in each OMNR region to present issues, concerns and information relevant to these areas to the provincial board.

In developing rules and standards, the species, terrain and management objectives of forestry in the province must be considered. The standards should be clearly defined and any technical terminology employed should be defined to avoid misunderstandings. Finally the strictness of the standards must also be considered. It is clear that regulations that are too strict will force marginal firms out of business or small private landowners to take land out of forestry. On the other hand, if the regulations are too weak, little improvement in forest management will result.

The success of regulatory legislation is dependent in part on the degree of commitment offered by the administrative agency and the cooperation of landowners and operators. Responsibility for implementing the legislation should be placed with one agency; however, the involvement of other agencies should be encouraged. Sufficient funds and personnel are necessary to ensure a minimal level of enforcement. The costs of administration and enforcement can vary according to factors such as the nature and requirements of the legislation and the number and location of timber operations. Review of timber harvesting plans and 
notifications and site inspections represent the two major costs in most states.

Procedures for inspecting operations to check for compliance should be established. Important in this respect is the establishment of criteria to determine the priority of operations for inspection, and the provision of adequate and suitably-qualified enforcement personnel. Furthermore, as compliance with the regulations involves a behavioural change and a cost to most landowners and operators, a range of penalties for non-compliance should be available depending on the nature of the violation. What appears to be necessary is a balance between punitive enforcement and education and cooperation, and for this reason verbal warnings and discussions in the field are recommended in certain situations.

The success of regulations of this type will also depend greatly upon the attitude of the regulated parties and therefore every effort must be taken to publicize and promote the standards effectively. Unless the regulated are fully aware of the regulations and understand them, little will be achieved in improving forest management.

Finally, any development of forest practice legislation must recognize the existing legislation affecting private land forestry in Ontario. Two options exist, either replacing existing legislation with a comprehensive forest practice act or amending existing legislation to ensure compatibility with forest practice legislation. The potential to improve the management of private land forests through forest practice regulations will be undermined if they contradict other programs or if these programs provide a means of avoiding the regulations.

\section{Acknowledgements}

The authors are grateful to the University of Guelph and the Ontario Ministry of Natural Resources for their support and to Bob Staley of the Ministry for his encouragement and guidance.

\section{References}

Aird, Paul L. 1980. Government incentives and disincentives to private land forestry. Ontario Ministry of Natural Resoruces, Toronto.

Armson, K. 1976. Forest Management in Ontario. Ontario Ministry of Natural Resources, Toronto.

Ellefson, P.V. and F.W. Cubbage. 1980. State forest practice laws and regulations: A review and case study for Minnesota. Univ. Minn. Agric. Exp. Stn. Bul. 53C.

Idaho Dept. of Lands. 1984. Current analysis by field personnel on what is needed to improve the Forest Practice Act. Rep. by the Bureau of Private Forestry, Boise, Idaho.

Jones, C.O. 1977. An Introduction to the Study of Public Policy. Massachusetts: Duxbury Press.

Kreutzwiser, R.D. 1982. An evaluation of government response to the Lake Erie shoreline flood and erosion hazard. Can. Geog. 26: 263-273.

Ontario Ministry of Natural Resources. 1982. Private Forest Lands - A Public Resource. Toronto.

Puddister, M.J. and R.D. Kreutzwiser. 1984. Legislating local tree conservation. Jour. Soil and Water Conserv. 39: 110-112.

Sewell, W.R.D. 1973. Broadening the approach to evaluation in resources management decision-making. Jour. Environ. Manage. 1: 33-60.

Smyth, J.H. and I.A. Nausedas. 1982. Rural lands and landowners of Ontario: A private land forestry perspective. Can. For. Serv. and Ont. Min. Nat. Resour. Toronto.

Society of American Foresters. 1975. Final report of the task force on forest practices. Jour. For. 73: 803-807.

Society of American Foresters. 1981. Criteria for a Competent State Forest Practices Act. A Position of the Society of American Foresters, Washington, D.C.

Weiss, C.H. 1972. Evaluation Research. Englewood Cliffs: PrenticeHall Inc.

Weyerhaeuser Company 1975. State forest practice acts. Paper presented at the American Forestry Association Workshop on Forest Practices and Water Quality, Atlanta, Georgia.

\section{Retired Members}

This note is to remind retired members and Section Councils about the provisions of By Law 4.4 which allows individuals who have been Institute members for 15 or more years and who retire "with a substantial reduction in income" to apply for retired status. If approved, retired status members are not required to pay any dues, but retain all rights and benefits except receipt of The Forestry Chronicle. The Chronicle is available to retired members on payment of the regular subscription rate for individuals (\$28.00 for 1986).

The proper procedure for those interested in this provision is to apply to your Section Council. Councils will deal with these applications and notify National Office of the decision so that records can be adjusted.

R.J. Bourchier

Executive Director 